\title{
FHL2 expression in peritumoural fibroblasts correlates with lymphatic metastasis in sporadic but not in HNPCC-associated colon cancer
}

\author{
Lucia Gullotti ${ }^{1}$, Jacqueline Czerwitzki ${ }^{2}$, Jutta Kirfel ${ }^{1}$, Peter Propping ${ }^{3}$, Nils Rahner ${ }^{3}$, Verena Steinke ${ }^{3}$, Philip Kahl ${ }^{2}$, \\ Christoph Engel ${ }^{4}$, Roland Schüle ${ }^{5}$, Reinhard Buettner ${ }^{2}$ and Nicolaus Friedrichs ${ }^{2}$
}

Four and a half LIM domain protein-2 (FHL2) is a component of the focal adhesion structures and has been suggested to have an important role in cancer progression. This study analyses the role of FHL2 in peritumoural fibroblasts of sporadic and hereditary non-polyposis colorectal cancer (HNPCC). Tissue specimens of 48 sporadic and 49 hereditary colon cancers, respectively, were stained immunohistochemically for FHL2, transforming growth factor (TGF)- $\beta 1$ ligand and $\alpha$-SMA. Myofibroblasts at the tumour invasion front co-expressed $\alpha$-SMA and FHL2. Sporadic colon cancer but not HNPCC cases showed a correlation between TGF- $\beta 1$ expression of the invading tumour cells and FHL2 staining of peritumoural myofibroblasts. Overexpression of FHL2 in peritumoural myofibroblasts correlated to lymphatic metastasis in sporadic colon cancer but not in HNPCC. In cultured mouse fibroblasts, TGF- $\beta 1$ treatment induced myofibroblast differentiation, stimulated FHL2 protein expression and elevated number of migratory cells in transwell motility assays, suggesting that FHL2 is regulated downstream of TGF- $\beta$. Physical contact of colon cancer cells and myofibroblasts via FHL2-positive focal adhesions was detected in human colon carcinoma tissue and in co-culture assays using sporadic as well as HNPCC-derived tumour cell lines. Our data provide strong evidence for an important role of FHL2 in the progression of colon cancers. Tumour-secreted TGF- $\beta 1$ stimulates FHL2 protein expression in peritumoural fibroblasts, probably facilitating the invasion of tumour glands into the surrounding tissue by enhanced myofibroblast migration and tight connection of fibroblasts to tumour cells via focal adhesions. These findings are absent in HNPCC-associated colon cancers in vivo and may contribute to a less invasive and more protruding tumour margin of microsatellite instable carcinomas.

Laboratory Investigation (2011) 91, 1695-1705; doi:10.1038/labinvest.2011.109; published online 8 August 2011

KEYWORDS: FHL2; HNPCC; metastasis; peritumoural fibroblast; sporadic colon cancer; TGF- $\beta 1$

Four and a half LIM domain protein-2 (FHL2) was first identified as a protein differentially expressed in human myoblasts and rhabdomyosarcoma cells, and thus named DRAL (downregulated in rhabdomyosarcoma LIM protein ${ }^{1}$ ). FHL2 is a LIM-only protein with four complete and one $\mathrm{N}$-terminal half LIM domains that mediate protein-protein interactions. ${ }^{2}$ FHL2 associates with integrin receptors to form focal adhesion contacts and binds signal transducers such as $\beta$-catenin. ${ }^{3-5}$ Triggered by lipid-induced signalling, such as sphingosine-1-phosphate, FHL2 translocates into the nucleus where it binds several transcription factors including serum response factor, AP1 and androgen receptor and functions as a coactivator or a corepressor to modulate gene expression. $^{6-8}$

We showed previously that FHL2 is strongly upregulated in mesenchymal cells of wounded skin, and demonstrated a function of FHL2 in myofibroblasts regulating their migration and contraction during cutaneous wound healing. ${ }^{9}$ Furthermore, FHL2 is critically involved in matrix assembly allowing migration of cells into the wound area. ${ }^{10}$ Analogous to wound healing invasive carcinomas generate a specialised tumour stroma and deposit a matrix facilitating invasion into

\footnotetext{
${ }^{1}$ Institute of Pathology, University of Bonn Medical School, Bonn, Germany; ${ }^{2}$ Institute of Pathology, University of Cologne Medical School, Cologne, Germany; ${ }^{3}$ Institute of Human Genetics, Biomedical Centre, University of Bonn, Bonn, Germany; ${ }^{4}$ Institute of Medical Informatics, Statistics and Epidemiology, University of Leipzig, Leipzig, Germany and ${ }^{5}$ Center for Clinical Research, University of Freiburg Medical School, Freiburg, Germany

Correspondence: N Friedrichs, MD, Institute of Pathology, University of Cologne Medical School, Kerpener Strasse 62, Cologne 50924, Germany.

E-mail: friedrin@gmx.de

Received 26 January 2011; revised 22 April 2011; accepted 7 June 2011
} 
the surrounding tissue. ${ }^{11}$ This tissue remodelling is induced by pro-metastatic factors, such as transforming growth factor (TGF)- $\beta 1$, which is secreted by the tumour cells inducing the conversion of mesenchymal cells into myofibroblasts. ${ }^{12-15}$

A number of studies from our laboratory and other groups provide evidence that FHL2 is involved in cancer progression. ${ }^{16-21}$ Elevated expression of FHL2 and interaction with focal adhesion kinase (FAK) was found in human ovarian cancers, indicating a role of FHL2 and FAK complex during ovarian tumour progression. ${ }^{17}$ We showed recently that activation of nuclear FHL2 signalling is linked to an aggressive biology and recurrence of prostate cancer. ${ }^{18}$ Wang et $a l^{21}$ showed that suppression of FHL2 in gastric and colon cancer cell lines induces cell differentiation and inhibits tumorigenesis. Analysing various colon cancer cell lines, Zhang et al ${ }^{19,20}$ showed that FHL2 expression and epithelialmesenchymal transition (EMT) can be induced by TGF- $\beta 1$.

This study aimed to determine the role of FHL2 in progression of colorectal carcinoma focussing on stromal fibroblasts. As TGF- $\beta 1$ is known as a signalling molecule promoting invasion of colorectal cancer, we asked specifically whether TGF- $\beta 1$ signalling is able to modulate FHL2 expression and determined, whether FHL2 expression patterns provide prognostic information concerning aggressive biology and metastasis. We specifically compared FHL2 expression in sporadic and microsatellite-instable hereditary (hereditary non-polyposis colorectal cancer (HNPCC)) colon cancers, which are known to invade in a less aggressive and more protruding-type manner ${ }^{22}$ and reveal less EMT.

\section{MATERIALS AND METHODS}

\section{Patient Collective}

Paraffin-embedded tissue specimens of 97 patients were examined comprising 48 cases of sporadic colon cancer and 49 cases of hereditary HNPCC patients with proven germline mutation in mismatch repair genes. Clinical data are summarised in Table 1. Samples of sporadic colorectal cancer cases were recruited from the archive of the Institute of Pathology (years 2002-2006), specimens of HNPCC patients were taken from the archive of the German HNPCC Consortium (2003-2006).

\section{Immunohistochemistry and Immunofluorescence}

\section{Staining procedure for TGF- $\beta 1$ ligand, FHL2 and $\alpha-S M A$}

Haematoxylin-eosin staining was performed for routine pathological evaluation followed by staining and subsequent evaluation of TGF- $\beta 1$ ligand, FHL 2 and $\alpha$-SMA. Immunohistochemical $\alpha$-SMA staining was carried out as described before. $^{23}$

The staining procedure for TGF- $\beta 1$ ligand and FHL2 was carried out as described briefly: tissue sections were incubated overnight at $60^{\circ} \mathrm{C}$, deparaffinised for $2 \times 10 \mathrm{~min}$ in xylene, followed by $5 \mathrm{~min}$ in $100 \%$ ethanol. Then slides were put for $5 \mathrm{~min}$ in $96 \%$ and subsequently in $70 \%$ ethanol and for another $5 \mathrm{~min}$ in distilled water. For better antigen

Table 1 Clinical data of 97 cases of sporadic and HNPCC-associated colon carcinomas

Sporadic colon cancer

$(n=48)$

\section{Age (years) \\ $<50$ \\ $\geq 50$ \\ Age (mean) \\ Gender \\ Female \\ Male

Tumour size
pTx
pT1
pt2
pt3
pt4

Nodal status

pNx

pno

pn1

pn2

Tumour grade

G1

G2

G3
Abbreviation: HNPCC, hereditary non-polyposis colorectal cancer.

retrieval, samples were boiled in a microwave oven in citrate buffer ( $\mathrm{pH}$ 6.0). Then samples were cooled down for $20 \mathrm{~min}$, washed in PBS for $5 \mathrm{~min}$ and incubated for $10 \mathrm{~min}$ in $10 \%$ normal pig serum. The samples were incubated over night at $4^{\circ} \mathrm{C}$ with rabbit anti-human FHL2 antibody (Schüle Laboratory) used at a dilution of 1:250 or with rabbit anti-human TGF- $\beta 1$ ligand antibody (clone sc-146, Santa Cruz, Santa Cruz, CA, USA) at a dilution of 1:50 for $1 \mathrm{~h}$ at room temperature. The samples were washed twice for $5 \mathrm{~min}$ in PBS and then incubated at room temperature for $30 \mathrm{~min}$ with the biotinylated secondary antibody. Subsequently, a washing step in PBS for $5 \mathrm{~min}$ and a peroxidase block with $\mathrm{H}_{2} \mathrm{O}_{2}$ for $10 \mathrm{~min}$ was carried out. After washing in PBS for $5 \mathrm{~min}$, streptavidine horseradish peroxidase was applied for $30 \mathrm{~min}$ followed by washing in PBS and subsequent visualisation with diaminobenzidine tetrahydrochloride (Sigma, Hamburg, Germany). 
After a final washing step, slides were counterstained with Mayer's haematoxylin, dehydrated and mounted.

Immunofluorescence stainings using the antibodies mentioned above were performed as described before. ${ }^{24}$

\section{Evaluation of immunohistochemical staining intensities of TGF- $\beta 1$ ligand and FHL2}

Evaluation of immunohistochemical staining intensities was restricted to the carcinoma invasion front. TGF- $\beta 1$ ligand expression of invasive tumour epithelia or FHL2 expression of peritumoural fibroblasts at the invasion front were analysed using a four-tier scoring system: staining intensity was set to score value ' 0 ' if no staining was present. Score ' $1+$ ' was used if weak staining of cells was observed, score ' $2+$ ' ' if moderate and score ' $3+$ ' if strong staining of cells was detected. Overexpression of the respective marker was diagnosed if staining reaction was classified as ' $2+$ ' or ' $3+$ '. In cases with heterogeneous staining reactions, eg, because of varying tumour differentiation, the immunoreactive score was determined analysing the predominant area of tumour differentiation. Immunohistochemical scoring was carried out by a trained pathologist (NF) who was blinded for the results of follow-up data and data used for subsequent statistical analyses.

\section{Immunofluorescence Microscopy}

Images were taken by using a Leica TCS SP2 AOBS spectral confocal microscope (Leica, Solms, Germany) or a Leica DMLB2 fluorescence microscope (Leica, Solms, Germany) equipped with the image analysis software 'Diskus' (Diskus, Königswinter, Germany).

\section{Western Blot}

Soluble protein lysates were extracted in $150 \mathrm{mM} \mathrm{NaCl}$, $10 \mathrm{mM}$ Tris ( $\mathrm{pH} 7.2$ ), $0.1 \%$ SDS, $1 \%$ Triton X-100, $1 \%$ deoxycholate and $5 \mathrm{mM}$ EDTA and centrifuged at $13000 \mathrm{~g}$ for $20 \mathrm{~min}$ at $4^{\circ} \mathrm{C}$. Protein lysates $(15 \mu \mathrm{g})$ were denatured at $90^{\circ} \mathrm{C}$ for $10 \mathrm{~min}$, run on $12 \%$ SDS-PAGE gels and electroblotted to a PVDF membrane (Roti-PVDF, Roth GmbH, Karlsruhe, Germany) using standard protocols. After blocking in $5 \%$ non-fat dry milk/PBST for $2 \mathrm{~h}$, the membranes were incubated for $1 \mathrm{~h}$ with a mouse monoclonal anti-FHL2 antibody $^{25}$ (dilution 1:2000), a mouse monoclonal anti- $\alpha$ SMA antibody (dilution 1:600; DAKO, Glostrup, Denmark), washed, incubated with horseradish peroxidase-conjugated secondary antibody (dilution 1:1000; Dako, Hamburg, Germany) and developed using ECL chemiluminescence (Amersham Biosciences, Little Chalfont, UK). As a control, blots were probed with an anti- $\alpha$-tubulin antibody (dilution 1:5000, Sigma, Hamburg, Germany).

\section{Tissue Culture}

Murine embryonal fibroblasts were derived from 14.5-daysold embryos of C57BL/6 wild-type or FHL2-deficient mice as described previously. ${ }^{9}$
Mouse fibroblasts were plated onto $15 \mathrm{~cm}$ dishes and grown to $75 \%$ confluency in DMEM supplemented with $10 \%$ FCS. Then the cells were grown in low serum (DMEM supplemented with $0.5 \%$ FCS) for $48 \mathrm{~h}$ and treated with $2 \mathrm{ng} / \mathrm{ml}$ recombinant human TGF- $\beta 1$ (Tebu, Offenbach, Germany) in low serum conditions for different time points $(0,24,72$ and $96 \mathrm{~h}$ ). The medium was changed every $24 \mathrm{~h}$. For each time point, starved cells incubated with low serum were used as control. All experiments were repeated at least three times.

\section{Co-culture Assay of Fibroblasts and Tumour Cell Lines}

Fibroblasts were seeded using DMEM supplemented with $10 \%$ FBS followed by a $48 \mathrm{~h}$ interval of low serum conditions. Subsequently, TGF- $\beta 1$ ligand $(2 \mathrm{ng} / \mathrm{ml})$ was added to fibroblast culture for $48 \mathrm{~h}$. In parallel, colon cell lines were cultured in low serum conditions $(0.5 \%$ FBS $)$ for $48 \mathrm{~h}$. TGF- $\beta 1$ ligand $(2 \mathrm{ng} / \mathrm{ml})$ was added to co-culture $(25000$ fibroblasts $/ \mathrm{ml}$ and 25000 tumour cells $/ \mathrm{ml}$ ) for $24 \mathrm{~h}$ followed by fixation of the cells and immunofluorescence staining (described below). For co-culture assays, microsatellite-stable (HT-29) and -instable colon carcinoma cell lines (HCT-116) were used.

\section{Transwell Motility Assay}

Transwell motility assays were performed as described before. ${ }^{26}$ In brief, fibroblasts were seeded using DMEM supplemented with $10 \%$ FBS followed by a $48 \mathrm{~h}$ interval of low serum conditions. Subsequently, TGF- $\beta 1$ ligand $(2 \mathrm{ng} / \mathrm{ml})$ was added to fibroblast culture for $72 \mathrm{~h}$. In all, 100000 cells in medium containing $0.5 \%$ FBS were added into the upper chambers of transwells of $6.5 \mathrm{~mm}$ diameter and $8.0 \mu \mathrm{m}$ pore size (Corning Costar Corporation, Bodenheim, Germany). FBS concentration in the lower chamber was $2 \%$. TGF- $\beta 1$ ligand $(2 \mathrm{ng} / \mathrm{ml})$ was added to the lower chamber. The dishes were incubated in a $37^{\circ} \mathrm{C}$ incubator $\left(5 \% \mathrm{CO}_{2}\right)$ for $6 \mathrm{~h}$ before removing the medium from the top wells. Membrane fixation was performed with $4 \%$ paraformaldehyde for $15 \mathrm{~min}$. After removal of the non-migrating cells from the upper chamber with a cotton swab, the membranes were stained with Harris' haematoxylin for 15-20 min and washed. Membranes were removed from the plastic holders and mounted on glass slides with Aquatex (Merck, Darmstadt, Germany). The migrated cells were counted in at least 10 fields of view $(\times 200$ magnification). All assays were performed in triplicate.

In a second co-culture transwell motility assay, HCT116 tumour cells were labelled with red QDot dye (Invitrogen, Darmstadt, Germany) and incubated with FHL2 wild-type or knockout (KO) fibroblasts labelled with green QDot dye. To quantify the amount of migrated tumour cells, the area covered by red fluorescence signals was calculated by imaging software analysing 10 fields of view at $\times 200$ magnification.

\section{Statistical Analyses}

Fisher's exact test or Mann-Whitney $U$-test was applied using Prism software (Graph Pad Prism, La Jolla, CA, USA). 
$P$-values $\leqslant 0.05$ were considered significant $\left({ }^{\mathrm{NS}} P>0.05=\right.$ not significant, ${ }^{\star} P=0.05=$ significant, ${ }^{*} P=0.001$ to $<0.05=$ very significant, ${ }^{* * *} P<0.001=$ extremely significant, Figure 6a).

In sporadic colon cancer collective, four cases were not included in statistical analyses, as nodal status was not known $(\mathrm{pNx})$. In the analysis of TGF- $\beta 1$ and FHL2 expression in sporadic colon cancer three additional cases were excluded because of insufficient immunoreactivity for TGF- $\beta 1$.

In HNPCC collective, five cases were not included in statistical analyses, as nodal status was not known $(\mathrm{pNx})$. In the analysis of TGF- $\beta 1$ and FHL2 expression in HNPCC, five additional cases were excluded because of insufficient immunoreactivity for TGF- $\beta 1$.

\section{RESULTS}

\section{FHL2 Is Differentially Expressed in Non-neoplastic and Neoplastic Colon Specimens}

In stromal myofibroblasts of normal colon tissue, FHL2 staining was nearly absent (Figure 1a, Supplementary Figures $1 \mathrm{~A}-\mathrm{C})$. Stromal cells adjacent to colon adenoma occasionally showed nuclear FHL2 expression (insert of Figure 1a). Stromal cells within carcinoma tissue virtually always showed intensive FHL2 staining (Figure 1b). In confocal images (Supplementary Figures 1D-F) and confocal 3D-reconstructions (Supplementary Movies 2A-C), FHL2 protein was detected in the cytoplasm as well as in the nucleus of myofibroblasts. Stromal cells at the tumour invasion front showed highly variable FHL2 staining from negative (Figure 1b) to strong FHL2 expression (Figure 1c).

Pronounced accumulation of myofibroblasts at the tumour invasion front was observed in most cases of sporadic colon cancer cases vanishing with growing distance from tumour glands (Figures 2a and c). In contrast, HNPCCassociated carcinomas showed dense lymphocytic infiltrates separating tumour epithelia from the surrounding normal tissue (Figures $2 \mathrm{~b}$ and $\mathrm{d}$ ).

Expression of FHL2 correlated with lymphatic metastasis (Table 2a) in sporadic colon cancer $(P=0.02502)$ and, inversely, in HNPCC $(P=0.03204)$.

\section{TGF- $\beta 1$ Ligand Expression in Non-neoplastic and Neoplastic Colon Specimens}

In normal colon mucosa, TGF- $\beta 1$ ligand was expressed in a faint, dot-like staining pattern located below the mucus plug

Figure 1 Differential expression of FHL2 in non-neoplastic and neoplastic colon tissue. No significant FHL2 expression in stromal cells of normal colon mucosa (a, right side). Few stromal cells adjacent to adenoma tissue express FHL2 (a, insert, stromal cells marked with arrows). In the adjacent carcinoma, a larger number of FHL2-positive stromal cells are present (a, insert). (b) Intermediate grade colon carcinoma tissue surrounded by dense lymphocytic infiltrates and absence of FHL2-immunopositive stromal cells in the invasion front. (c) Low-grade colon carcinoma with intensive FHL2 staining of stromal cells in the invasion front (scale bar in a: $500 \mu \mathrm{m}$, scale bar in insert of a: $100 \mu \mathrm{m}$, scale bars in $\mathbf{b}$ and $\mathbf{c}: 200 \mu \mathrm{m}$ ). of the enterocytes (Supplementary Figure 3A). In colon adenomas, frequently a strong dot-like staining of tumour cells below the mucus plug (Supplementary Figure 3A) was seen. In colon carcinoma, the expression of TGF- $\beta 1$ ligand in tumour cells was variable (Supplementary Figures 3B, C).
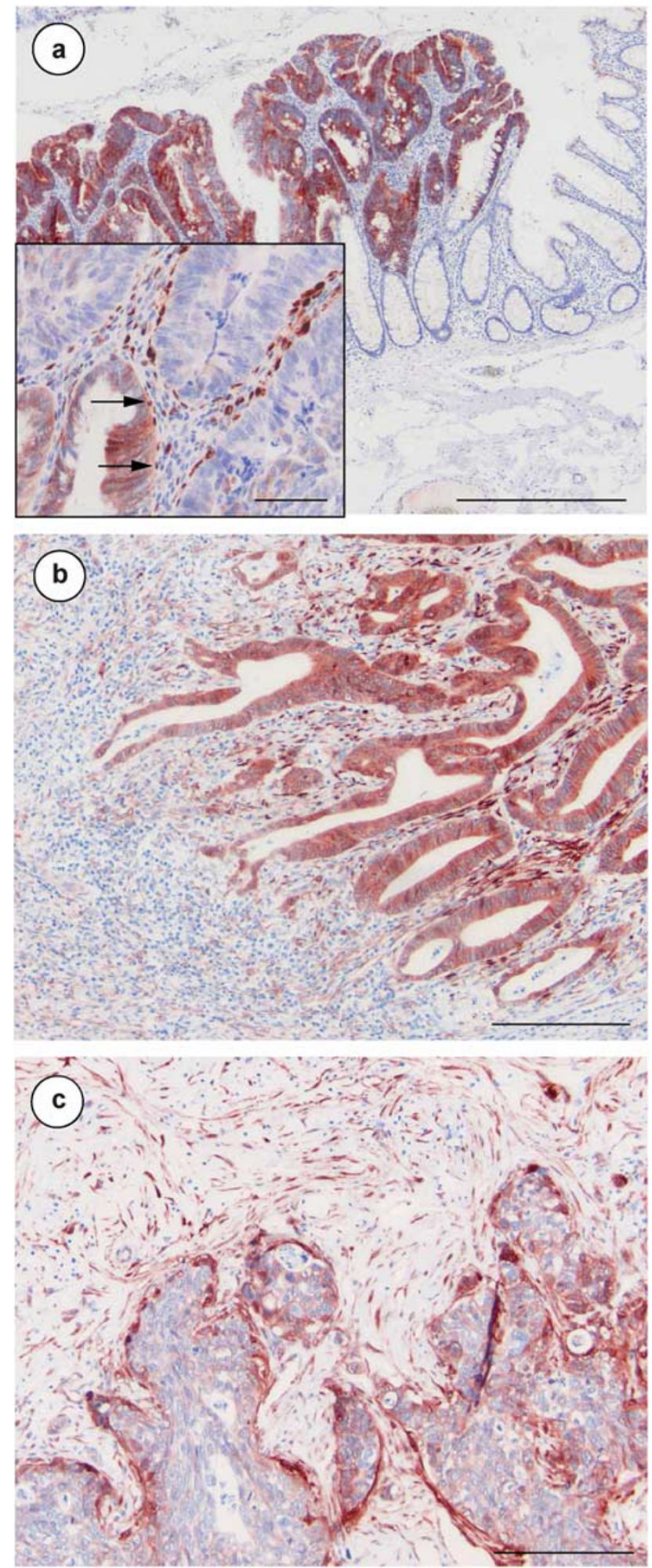
sporadic colon cancer
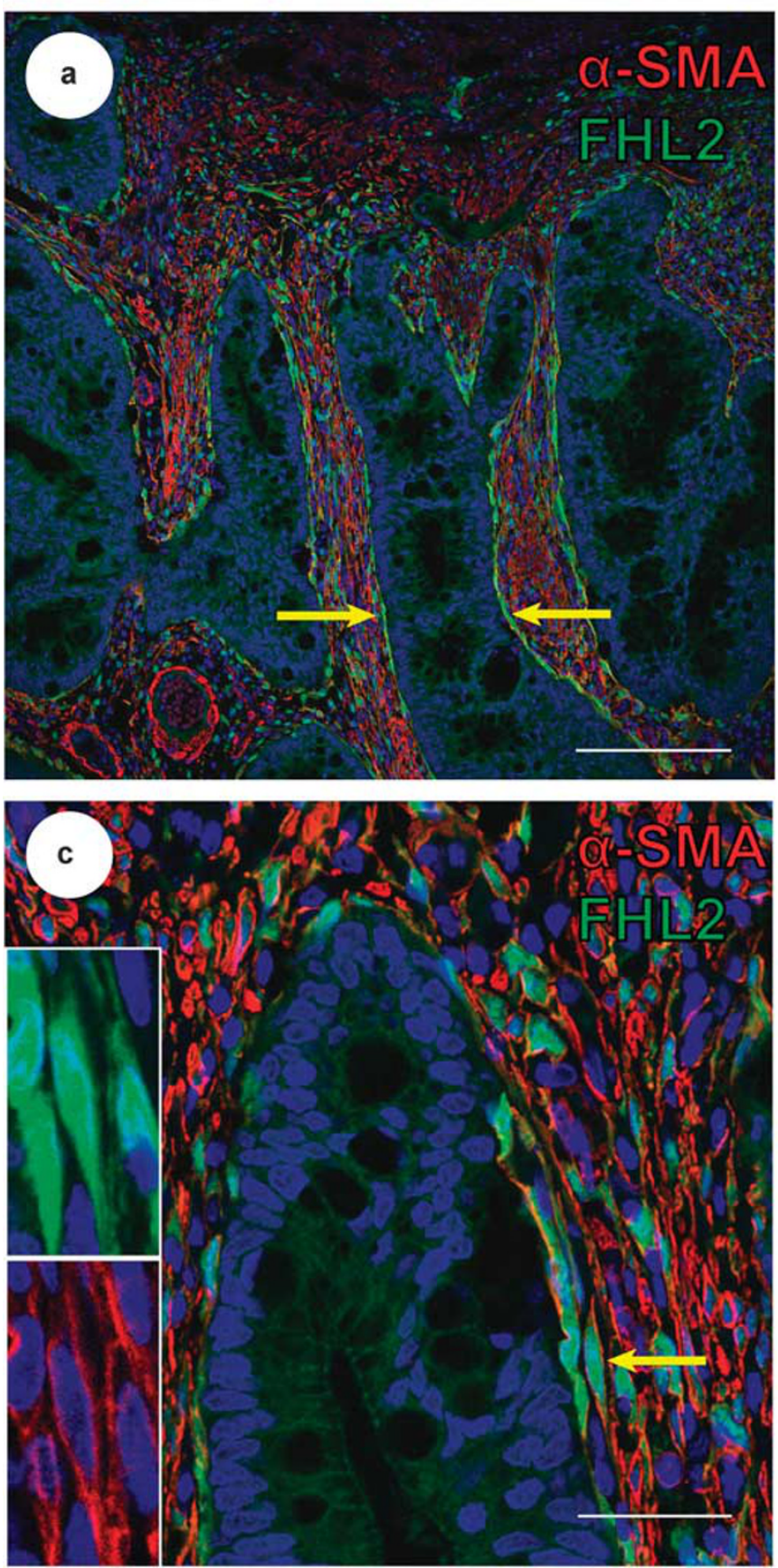

HNPCC
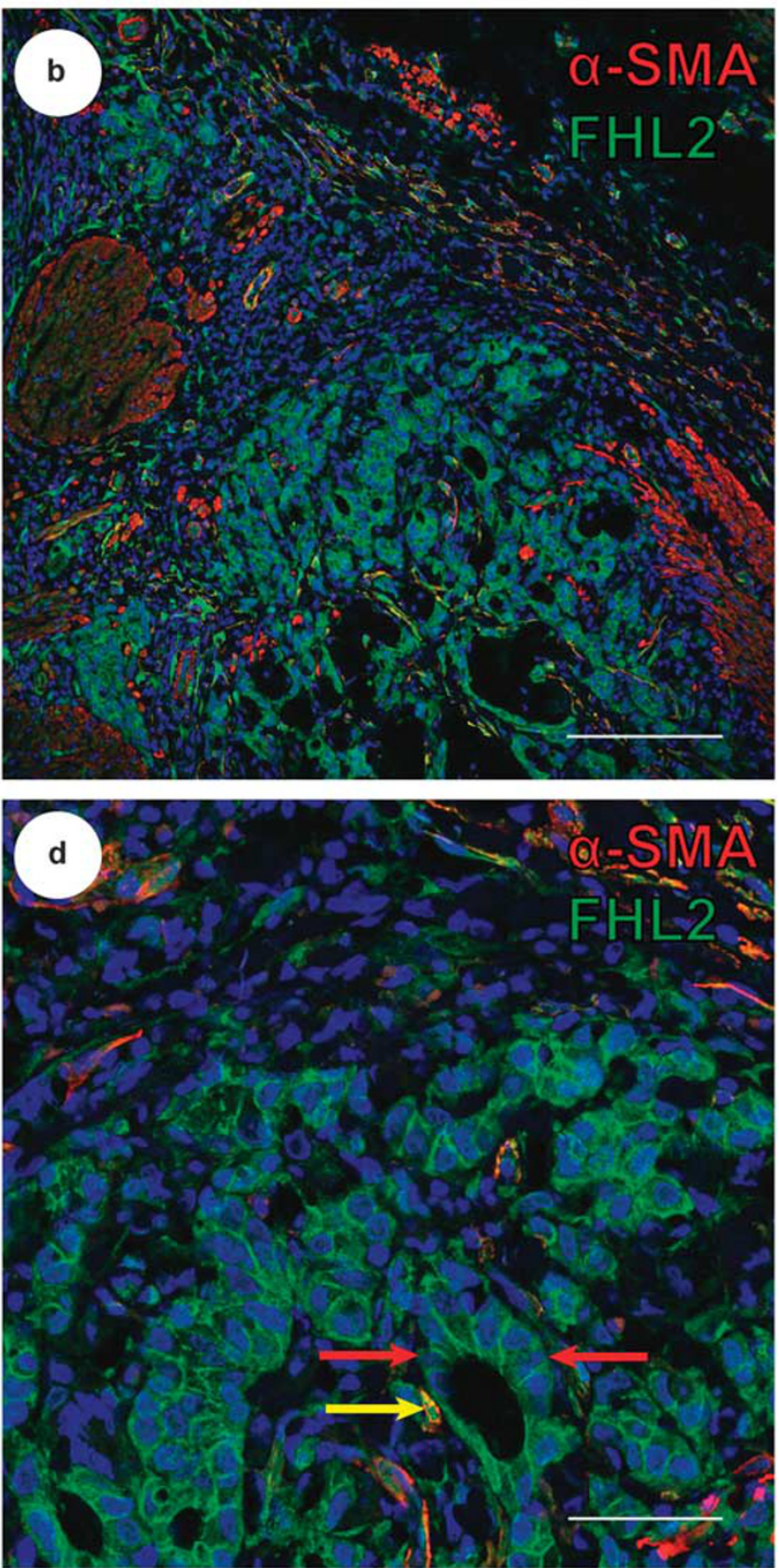

Figure $2 \mathrm{FHL} 2$ protein is strongly expressed in peritumoural myofibroblasts. FHL2-positive myofibroblasts attached to invading tumour cells are frequently found in sporadic colon cancer (a, c) but significantly less in HNPCC (b, d). FHL2 $+/ \alpha$-SMA + myofibroblasts are marked with yellow arrows, tumour cells are marked with red arrows. (c) Insert shows membranous expression of $\alpha$-SMA and nuclear/cytoplasmic expression of FHL2 in a myofibroblast. Note: dense DAPI-positive lymphocytic infiltrates in direct contact with HNPCC-associated carcinoma tissue in $\mathbf{b}$ and $\mathbf{d}$, and strong membranous but nearly absent nuclear FHL2 expression of ( $\alpha$-SMA-immunonegative) tumour cells in d (confocal images: scale bar in a and b: $150 \mu \mathrm{m}$, in $\mathbf{c}$ and $\mathbf{d}$ : $37.5 \mu \mathrm{m}$ ).

Tumour stromal cells located between carcinoma cells occasionally showed a weak staining reaction.

Expression of TGF- $\beta 1$ ligand in tumour cells went along with intensive expression of FHL2 and $\alpha$-SMA in adjacent stromal cells (Figure 3 ). A correlation of TGF- $\beta 1$ ligand expression in tumour cells with nuclear FHL2 expression of adjacent stromal cells in the tumour invasion front (Table $2 \mathrm{~b}$ ) was detected in sporadic carcinoma cases $(P=0.00355)$ but not in HNPCC $(P=0.33730)$. In contrast, colon carcinomas, which lacked TGF- $\beta 1$ ligand expression showed absence 
of FHL2 immunopositivity in tumoural myofibroblasts (Supplementary Figure 4).

\section{TGF- $\beta 1$-Treated Fibroblasts Show Enhanced FHL2 and Stable $\alpha$-SMA Expression}

We examined FHL2 protein expression after $0,24,72$ and $96 \mathrm{~h}$ of TGF- $\beta 1$ treatment (Figure 4 ). In wild-type fibroblasts, FHL2 protein expression was induced after 3 days of stimulation and persisted over basal levels for the entire

Table 2 (a) Lymphatic metastasis and FHL2 expression in sporadic colon cancer and HNPCC; (b) TGF- $\beta 1$ and FHL2 expression in sporadic colon cancer and HNPCC

\begin{tabular}{ccc}
$\begin{array}{c}\text { Sporadic colon cancer } \\
\text { (44 cases) }\end{array}$ & $\begin{array}{c}\text { HNPCC } \\
\text { (44 cases) }\end{array}$ \\
\cline { 5 - 6 } & FHL2+ FHL2- \\
\hline
\end{tabular}

(a)

\begin{tabular}{llccc} 
Lymphatic metastasis & 19 & 10 & 7 & 11 \\
No lymphatic metastasis & 4 & 11 & 19 & 7 \\
& $P=0.02502$ & & $P=0.03204$ \\
\hline
\end{tabular}

Sporadic colon cancer $\quad$ HNPCC

(41 cases) (39 cases)

(b)

$\begin{array}{lcrrr}\text { TGF- } \beta 1+ & 18 & 8 & 15 & 6 \\ \text { TGF- } \beta 1- & 3 & 12 & 10 & 8 \\ & P=0.00355 & & P=0.33730\end{array}$

Abbreviations: $\mathrm{FHL}$, four and a half LIM domain protein-2; HNPCC, hereditary non-polyposis colorectal cancer; TGF- $\beta$, transforming growth factor $\beta$.

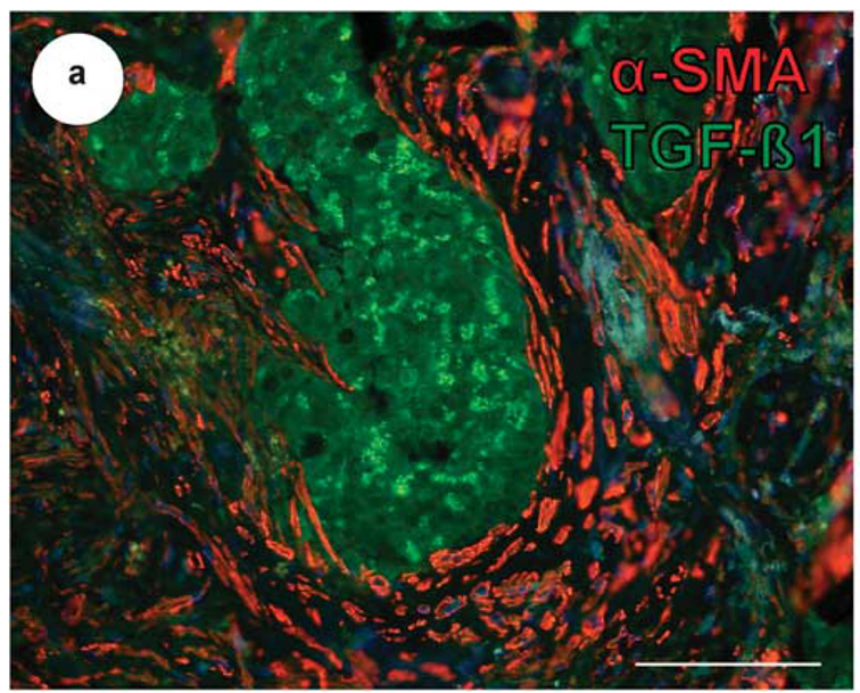

period until $96 \mathrm{~h}$. FHL2 expression was entirely absent in murine fibroblasts isolated from FHL2 KO mice ${ }^{9}$ before and after TGF- $\beta 1$ treatment. $\alpha$-SMA expression was not altered after TGF- $\beta 1$ treatment of both wild-type and KO fibroblasts (Figure 4).

\section{Subcellular Localisation of FHL2 and $\alpha$-SMA in Cultured Fibroblasts is Altered After TGF- $\beta 1$ Treatment}

In cultured fibroblasts, subcellular localisation of FHL2 was significantly changed by TGF- $\beta 1$ treatment and translocated to focal adhesion contacts (Figures $5 \mathrm{a}$ and $\mathrm{b}$ ). In wild-type fibroblasts, $\alpha$-SMA was homogenously expressed and not well organised (Figure $5 \mathrm{a}$ ). After $48 \mathrm{~h}$ of treatment with TGF- $\beta 1$, $\alpha$-SMA exhibited a typical localisation in stress fibres ranging through the entire cytoplasm and connected to focal adhesion contacts (Figures $5 \mathrm{a}$ and $\mathrm{b}$ ). Fibroblasts derived from FHL2 KO mice, as expected, showed no FHL2 staining before and after TGF- $\beta 1$ treatment and lacked recruitment of $\alpha$ SMA into stress fibres. These data strongly suggest that FHL2 is involved in TGF- $\beta 1$ signal transduction with respect to regulating $\alpha$-SMA, stress fibre organisation and a myofibroblast-like morphology.

From these data, we conclude that mouse primary fibroblasts increase FHL2 expression in response to TGF- $\beta 1$ treatment and express constant levels of $\alpha$-SMA, with a marked reorganisation of the cytoskeleton and an increased incorporation of $\alpha$-SMA into stress fibres, resulting in a myofibroblast-like cell phenotype. Importantly, FHL2 subcellular localisation to focal adhesions is also regulated by TGF- $\beta 1$.

\section{TGF- $\beta 1$ treatment and FHL2 expression elevated} number of fibroblasts with the capacity to migrate A transwell motility assay was applied to study the influence of TGF- $\beta 1$ treatment on the number of fibroblasts with the

Figure 3 TGF- $\beta 1$ expression coincides with myofibroblast differentiation and FHL2 expression of adjacent stromal cells. TGF- $\beta 1$-expressing sporadic

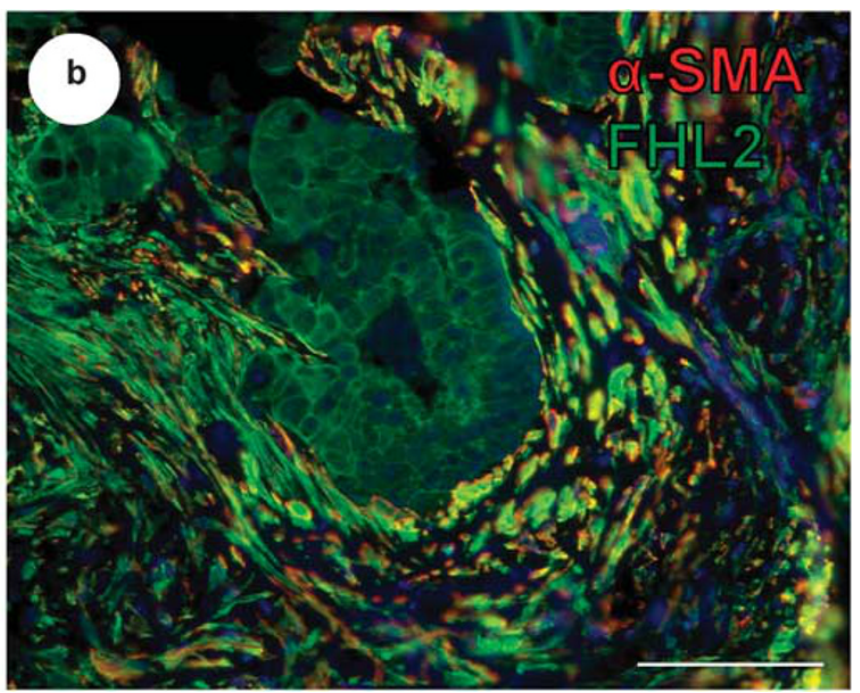

\footnotetext{
colon cancer cells (a) are surrounded by dense $\alpha$-SMA-immunopositive myofibroblast infiltrates, which co-express FHL2 (b; scale bars $=100 \mu$ m).
} 


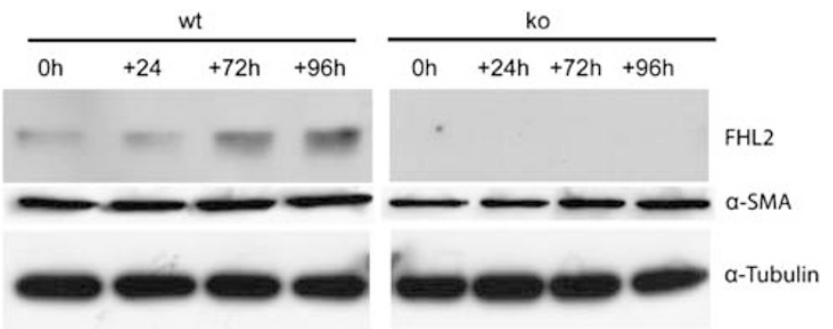

Figure 4 TGF- $\beta 1$-treated fibroblasts show enhanced FHL2 and stable $\alpha$-SMA expression in western blot. Mouse fibroblasts were serum starved for $48 \mathrm{~h}$ and treated with control medium or medium containing TGF- $\beta 1$ for different time points as indicated. $\alpha$-Tubulin served as loading control. Ko, knockout cells; wt, wild-type cells.

capacity to migrate. Untreated FHL2 KO fibroblasts showed less migrating cells compared with untreated wild-type cells $(P=0.035$, Figure 6a). A larger number of migrating cells was seen in TGF- $\beta 1$-treated wild-type fibroblasts compared with untreated wild-type fibroblasts $(P<0.001$, Figure 6a). TGF- $\beta 1$ treated FHL2 KO fibroblasts showed a significantly lower number of migrating cells compared with TGF- $\beta 1$ treated wild-type cells $(P<0.001$, Figure 6a). TGF- $\beta 1$-treated KO fibroblasts showed a significantly higher number of migrating cells $(P<0.001$, Figure 6a) than untreated $\mathrm{KO}$ fibroblasts (Figure 6a).

In a co-culture transwell motility assay, HCT116 tumour cells were labelled with red dye and incubated with FHL2 wild-type or KO fibroblasts labelled with green dye. The co-incubation assay with wild-type fibroblasts showed more tumour cell signals than the assay co-incubated with $\mathrm{KO}$ fibroblasts (Supplementary Figure 5). Though, we often observed a co-labelling of cells precluding a proper visual separation of individual cells. This co-labelling of cells might be explained by the ability of fibroblasts to perform phagocytosis $^{27}$ or by overlap of cytoplasmic tails of two individual cells with different dye label.

\section{Contact of Tumour Cells and Myofibroblasts In Vivo and In Vitro}

To analyse the contact of FHL2-positive myofibroblasts and colon cancer cells, paraffin-embedded human colon cancer tissue was stained for FHL2 and $\alpha$-SMA. A direct contact of myofibroblasts to tumour cells could be observed in sporadic colon cancer in vivo (Figures 6b-d).

Furthermore, an in vitro co-culture assay was established using sporadic (HT29) and HNPCC-derived (HCT116) colon cancer cell lines. Immunofluorescence stainings revealed that murine myofibroblasts were directly connected to tumour cells via FHL2positive focal adhesion contacts in sporadic colon cancer cell lines as well as in HNPCC-derived cell lines (Figures 6e and f).

\section{DISCUSSION}

This study analysed the role of the LIM-only protein FHL2 in tumour progression of sporadic colon cancer and HNPCC focussing on peritumoural myofibroblasts.
The role of FHL2 in tumorigenesis has been analysed in various cancer type, including carcinomas of the ovary, ${ }^{17}$ the breast $^{16}$ the prostate ${ }^{18}$ and the gastrointestinal tract. ${ }^{19,20}$ These studies mainly focussed on the role of FHL2 expression in malignant tumour cells proper. However, in addition to its expression in tumour cells, FHL2 might serve as a marker for characterisation of myofibroblast-like stromal fibroblasts in the tumour micromilieu. We previously determined an important role of FHL2 in myofibroblasts during wound healing. ${ }^{9}$ It has been shown that wounded tissue is comparable in several aspects to the tumour stroma as both are characterised by activated, $\alpha$-SMA-expressing myofibroblasts and deposition of provisional matrix and basal membrane molecules. ${ }^{11}$ As previous studies ${ }^{19,28}$ described an induction of FHL2 expression by TGF- $\beta 1$, this study considered both markers in the systematic analysis of colorectal tumour tissue and tumour stroma in vitro and in vivo.

Previous studies reported on the relevance of TGF- $\beta 1$ mediated tumour tissue remodelling for metastasis ${ }^{29}$ and also its specific role in progression of colon cancer. ${ }^{30}$ Therefore, we determined the expression patterns of FHL2, TGF- $\beta 1$ and $\alpha$-SMA, and their respective localisation in the micromilieu of sporadic and HNPCC-associated microsatellite-instable colon cancer in vivo. Normal colon mucosa showed no significant FHL2 expression of stromal fibroblasts, a finding which was also described by a previous study. ${ }^{21}$ In contrast, carcinoma tissue displayed elevated expression of FHL2 in stromal cells, which were identified as $\alpha$-SMA-positive myofibroblasts. Even in colon adenoma without signs of invasive growth myofibroblasts in direct contact to neoplastic epithelium revealed FHL2 expression indicating early preneoplastic stromal transformation. In 3D-reconstructions of peritumoural myofibroblasts by confocal microscopy, FHL2 protein was found in the cytoplasm and in the nucleus of these stromal cells (Supplementary Movies 2A-C). This observation confirms previous studies, which found that FHL2 serves as a signalling molecule and translocates into the nucleus acting as a transcriptional coactivator and corepressor. $^{6,8,25,31}$

Importantly, according to our data stromal FHL2 overexpression and the presence of myofibroblast-like stromal cells provided a significant parameter for lymphatic metastasis in sporadic colon cancer. In contrast, strong stromal FHL2 expression of HNPCC-associated tumours did not show prognostic relevance with regard to lymphatic spread, indicating that myofibroblastic remodelling of the tumour stroma may differ in these microsatellite-instable carcinomas. It is well known that HNPCC-associated colon cancers show a less invasive and more protruding, pushing-like tumour periphery, ${ }^{22}$ a lesser degree of EMT and reveal a better stageadjusted overall survival.

In this study, a positive correlation between TGF- $\beta 1$ expression of the tumour cells and FHL2 expression of the stromal cells was detected in sporadic colon cancer corresponding to observations of other studies. ${ }^{28}$ In contrast, 
a
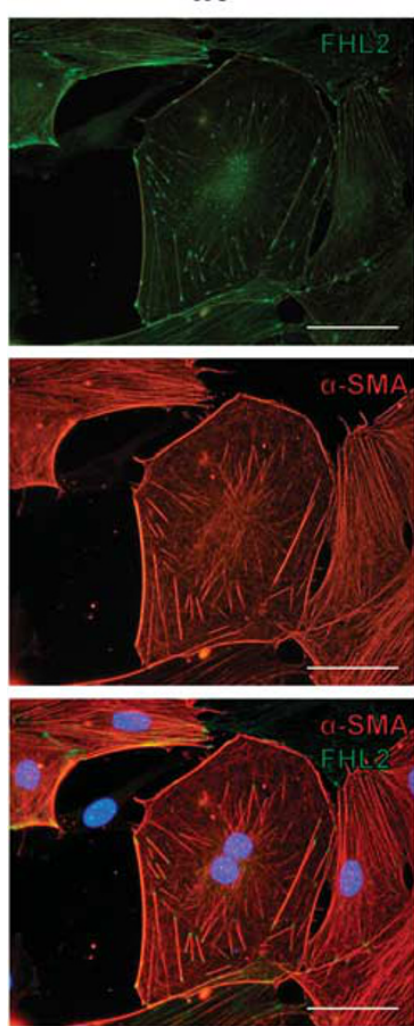

$w t+$ TGF-ß1
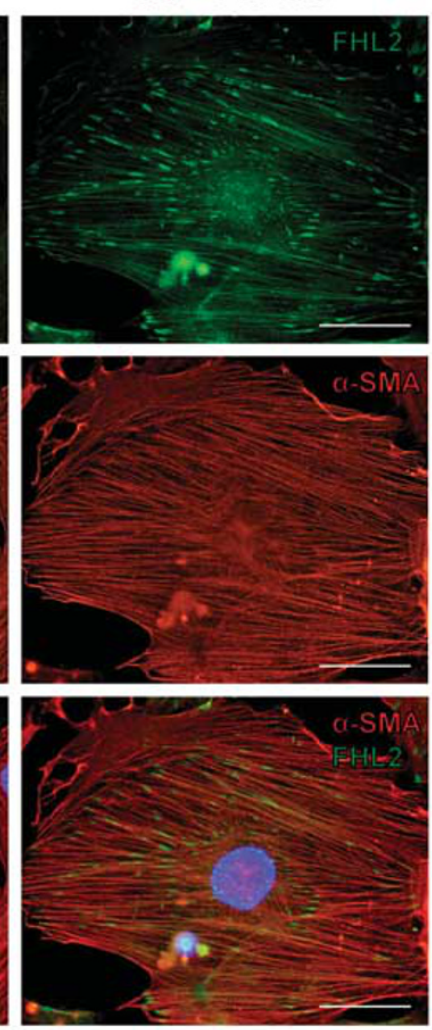

ko
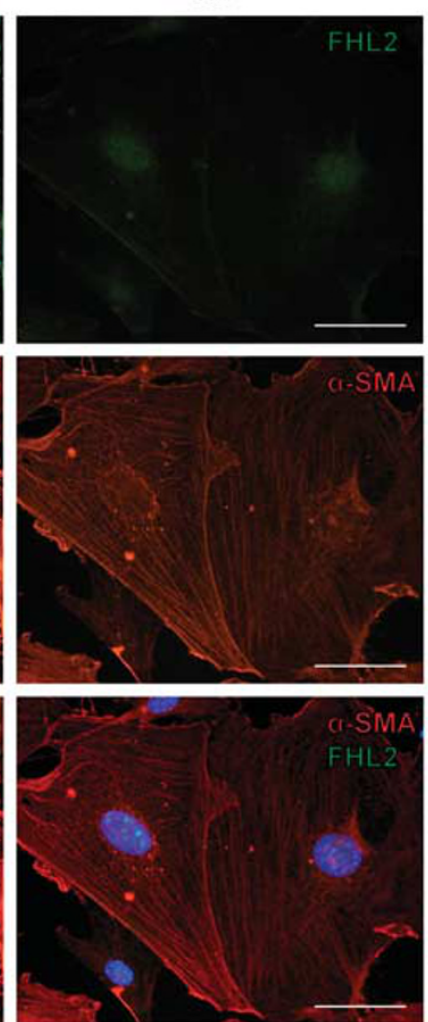

ko + TGF-ß1
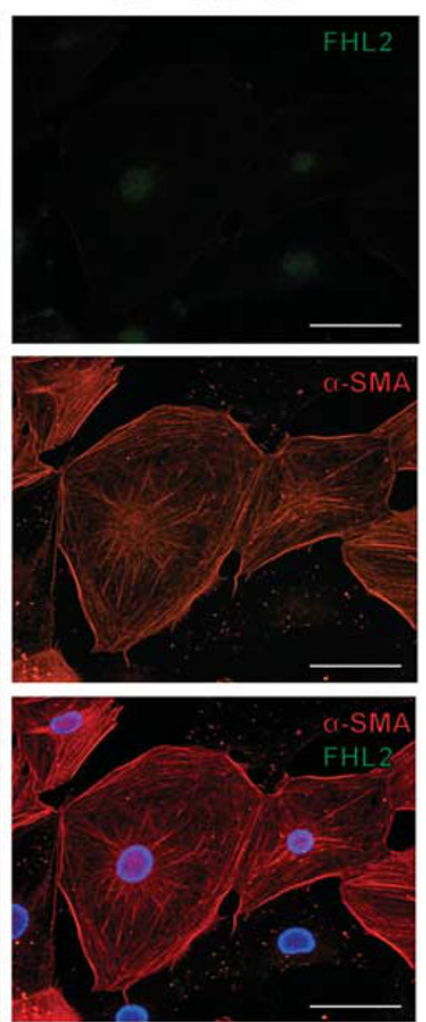

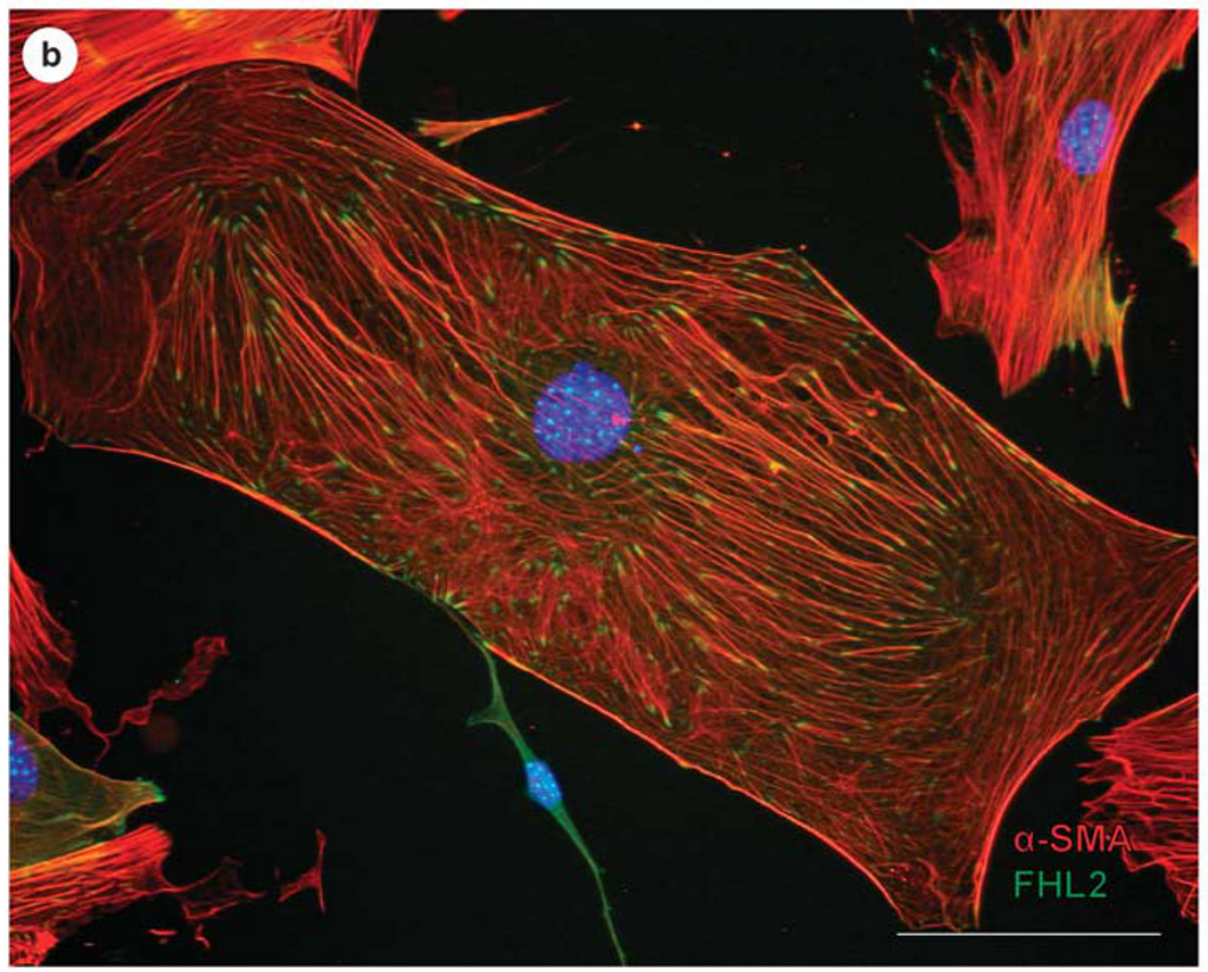

Figure 5 TGF- $\beta 1$ treatment of wild-type fibroblasts induces FHL2 translocation into focal adhesion contacts and redistribution of $\alpha$-SMA into stress fibres. (a) FHL2 and $\alpha$-SMA sublocalisation after TGF- $\beta 1$ induction. Fibroblasts derived from FHL2 wild-type and FHL2 knockout mice were treated with TGF- $\beta 1$ for $48 \mathrm{~h}$ and stained with FHL2 (green) and $\alpha$-SMA (red). Nuclei were stained with DAPI (blue). (b) Wild-type mouse primary fibroblast after $48 \mathrm{~h}$ treatment with TGF- $\beta 1$. Intensive expression of FHL2 (green) at the focal adhesion contacts and prominent $\alpha$-SMA staining (red) of stress fibres indicating a myofibroblast differentiation (all pictures: scale bar $=100 \mu \mathrm{m}$ ). 
significant correlation of TGF- $\beta 1$ expression and stromal FHL2 staining was not found in HNPCC-associated cancers, indicating that TGF- $\beta 1$ signalling from microsatellite-instable colon cancer cells may be defective. A histological difference between sporadic and HNPCC-associated cancers is the presence of dense lymphocytic infiltrates in the tumour micromilieu. ${ }^{22}$ Schwitalle et $a l^{32,33}$ recently showed that frameshift-induced neopeptides in HNPCC may induce this characteristic immune response. We therefore speculate that TGF- $\beta 1$-mediated interactions with myofibroblast-like stromal fibroblasts are altered in the presence of the immune response in HNPCC.

In cell culture assays of this study, TGF- $\beta 1$ induced FHL2 protein expression in fibroblasts. After induction, a
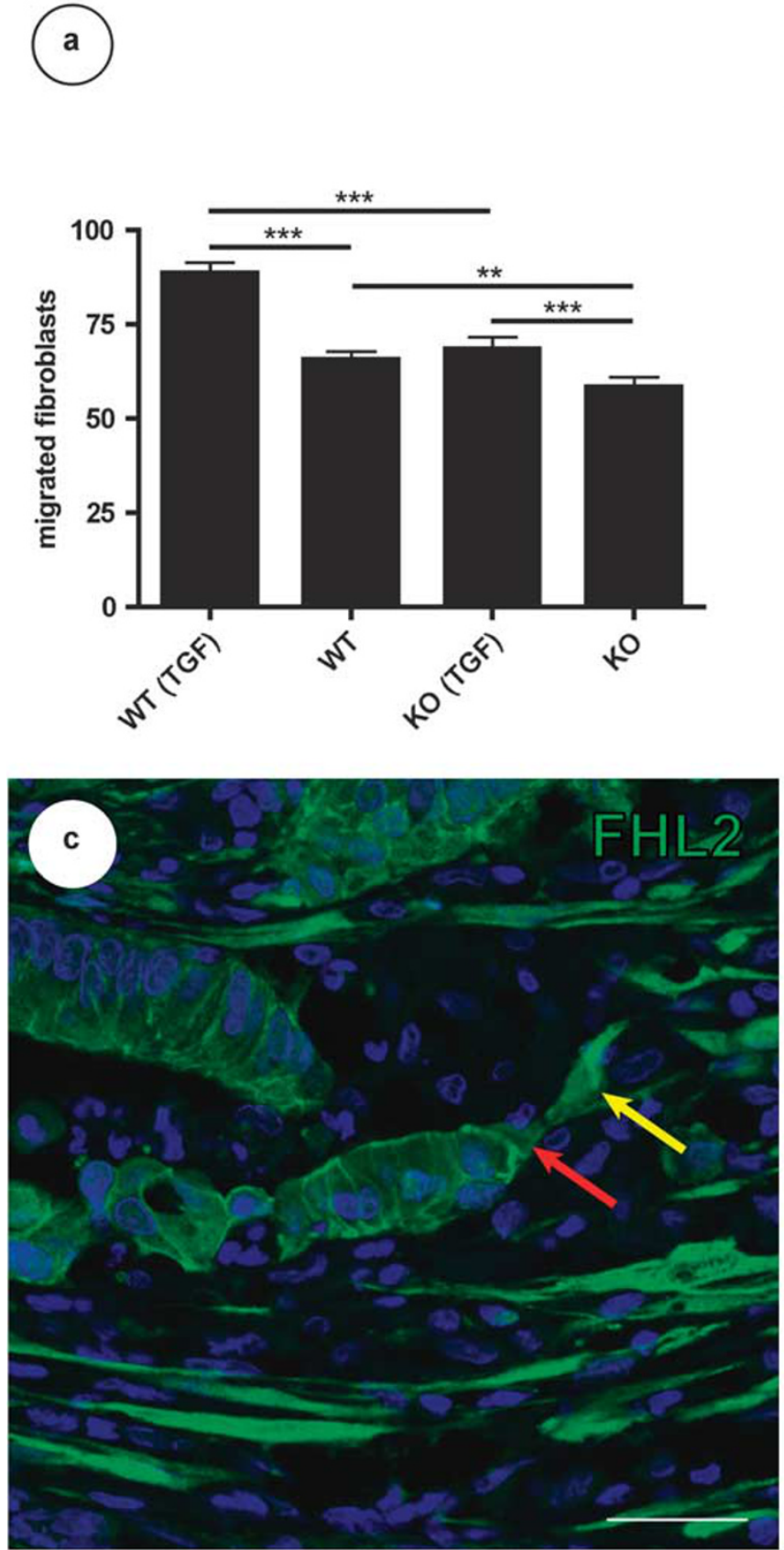
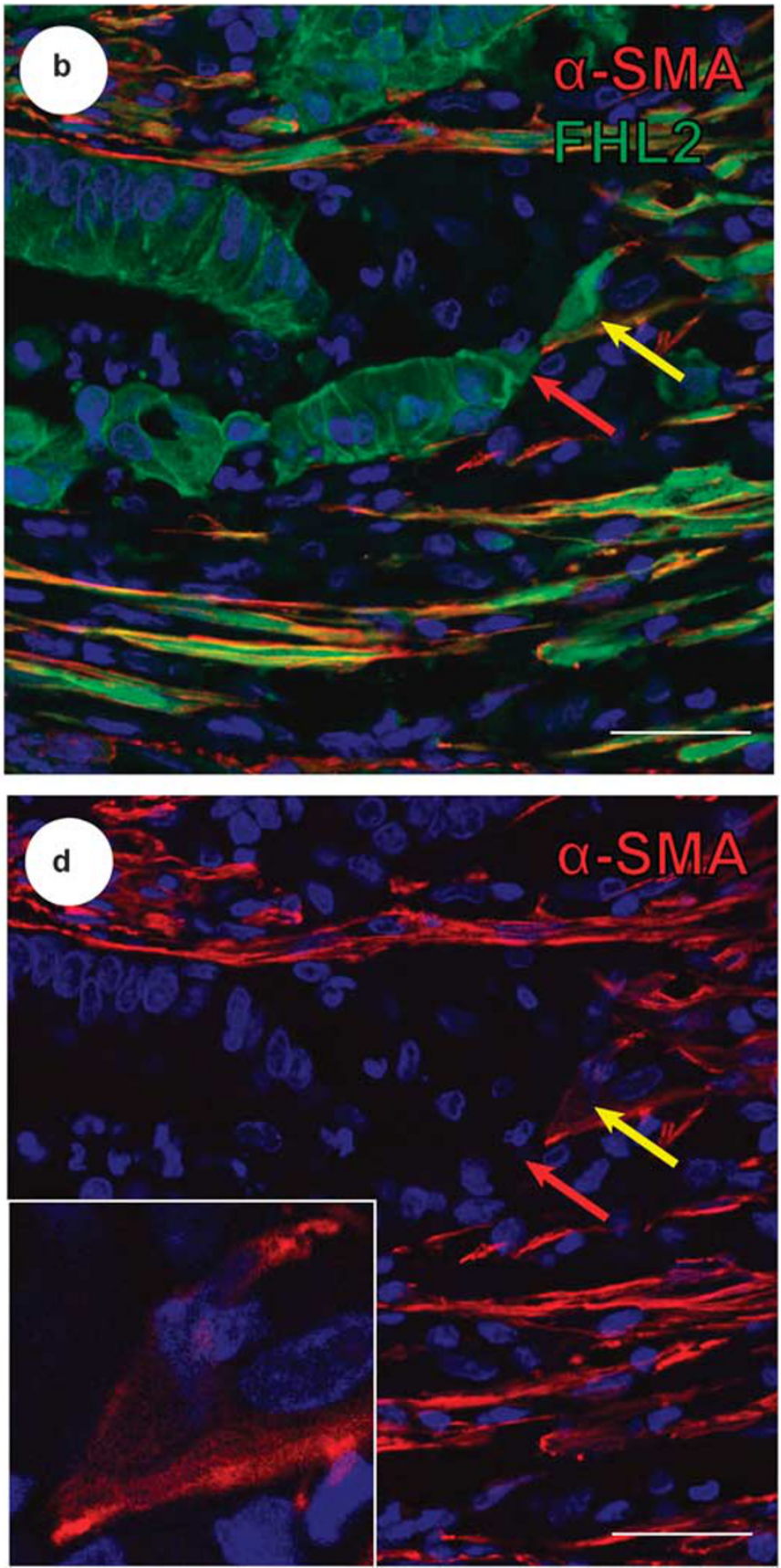

Figure 6 TGF- $\beta 1$ treatment and FHL2 expression elevate number of fibroblasts with the capacity to migrate (a) $\left({ }^{* * * P}<0.001,{ }^{* *} P=0.001\right.$ to $\left.<0.05\right)$. In sporadic human colon carcinoma contact of a FHL2 + $/ \alpha$-SMA + myofibroblast (yellow arrow) and a FHL2 $+/ \alpha$-SMA - tumour cell (red arrow) can be observed (b, overlay; $\mathbf{c}$, FHL2 staining; d, $\alpha$-SMA staining with insert showing the myofibroblast in detail). In vitro, co-culture assays show direct contact of fibroblasts (marked with yellow arrows) and tumour cells via focal adhesions in sporadic colon carcinoma cell line HT29 (marked with red arrows; e) but also in HNPCC cell line HCT-116 (marked with red arrows; f; confocal pictures: images b-d: scale bar $=36 \mu \mathrm{m}$, images e, $\mathbf{f}$ : scale bar $=50 \mu \mathrm{m}$ ). 

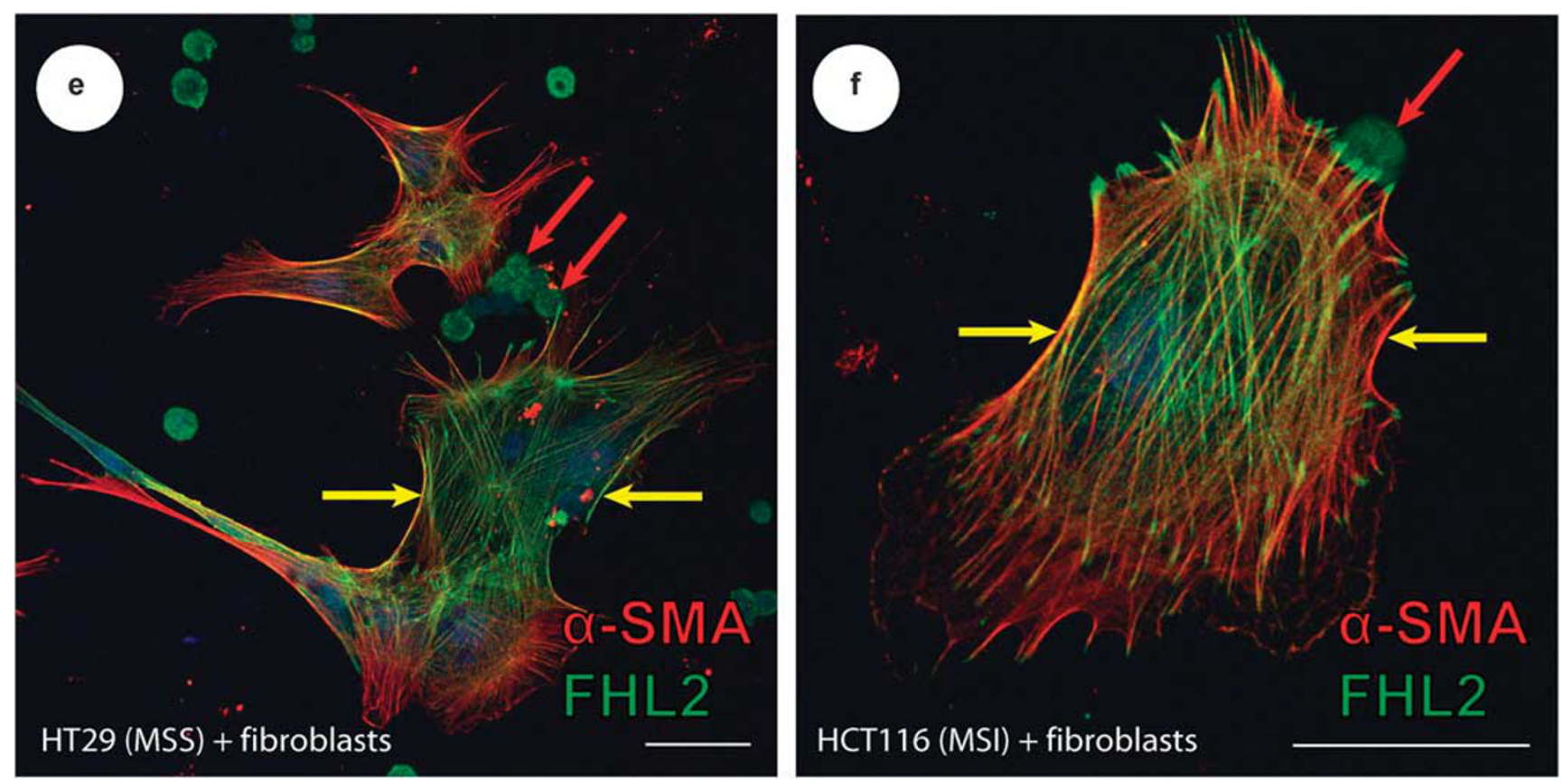

Figure 6 Continued.

myofibroblast-like differentiation was observed as described previously. ${ }^{7,34}$ Myofibroblasts coexpressed $\alpha$-SMA and FHL2 with a characteristic expression pattern of FHL2 at focal adhesion contacts as also observed in wounded tissue. ${ }^{9}$ It is therefore likely that TGF- $\beta 1$-induced, FHL2 overexpressing myofibroblasts form a highly mobile tumour stroma favouring migration, invasive growth and dissemination of colon cancer cells. The leading role of myofibroblasts in invasive growth of carcinomas has recently been described by Gaggioli et $a l,{ }^{35}$ who found that squamous cell carcinoma cells move collectively within tracks in the extracellular matrix behind the leading fibroblast remodelling the extracellular matrix. As TGF- $\beta 1$ is chemotactic for fibroblasts, ${ }^{36}$ the in vitro setting described above may well be transferred to in vivo cancer development.

Our in vitro data showed an elevated number of FHL2 wild-type fibroblasts with the capacity to migrate compared with FHL2 KO fibroblasts. This effect was also described previously concerning the role of fibroblasts in wound healing. ${ }^{9}$ These data point to an important role of FHL2 in migration of fibroblasts in general. Furthermore, we showed that treatment of fibroblasts with TGF- $\beta 1$ went along with a higher number of cells with the capacity to migrate, a finding which has also been reported in the literature before. ${ }^{15}$ In co-culture assays of this study, a connection of tumour cells to fibroblasts via focal adhesions was observed and detected both in sporadic and HNPCC-derived cell lines. As the dense peritumoural lymphocytic infiltrate typically found in HNPCC-associated cancers is not present in this co-culture assay, we speculate that the tight physical interaction between tumour cells and fibroblasts may be disturbed in vivo.
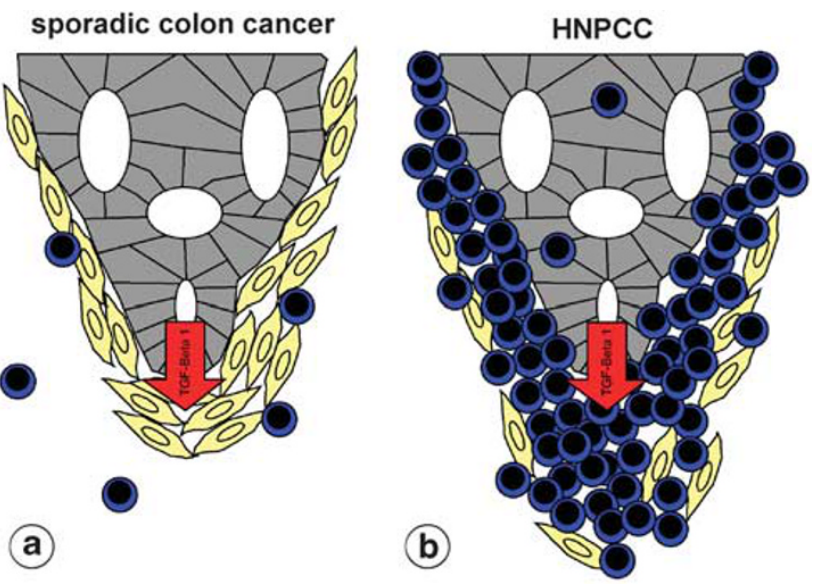

Figure 7 Model for interaction of FHL2-positive myofibroblasts (yellow) and colon cancer cells (grey). In sporadic colon cancer tumour-secreted TGF- $\beta 1$ induces myofibroblast accumulation densely attached to tumour tissue (a). In HNPCC lymphocytes (blue) separate myofibroblasts and tumour cells (b).

Taken together, the results of this study point to an important role of FHL2 in tumour-induced tissue remodelling, invasion and lymphatic metastasis of sporadic colorectal cancer, probably mediated by TGF- $\beta 1$-induced, FHL2-overexpressing myofibroblasts at the tumour invasion front. On the basis of our in vitro and in vivo findings, we postulate a model that in sporadic colon cancer tumour-secreted TGF- $\beta 1$ induces FHL2 expression in peritumoural myofibroblasts promoting the migration of 'leading' tumour cells into the surrounding stroma (Figure 7a). This phenomenon has been 
described previously for squamous cell carcinomas. ${ }^{35}$ These changes in the tumour micromilieu are not present in HNPCC-associated carcinomas, and we speculate that the extensive lymphocytic immune response may alter the TGF- $\beta 1$-mediated effects on stromal fibroblasts resulting in a less invasive growth pattern and less frequent lymphatic metastasis (Figure 7b). As FHL2 overexpression of myofibroblasts in sporadic colon cancer was significantly linked to lymphatic metastasis, we here propose FHL2 as a new prognostic marker indicating risk of lymphatic spread in colon cancers.

Supplementary Information accompanies the paper on the Laboratory Investigation website (http://www.laboratoryinvestigation.org)

\section{ACKNOWLEDGEMENTS}

We thank Barbara Reddemann, Susanne Steiner and Christiane Esch for their expert technical assistance. Lucia Gullotti was supported as a graduate within the Graduiertenkolleg 804 of the Deutsche Forschungsgemeinschaft. This work was supported by the BONFOR grant (BonFor-Program) to NF and by a grant from the Deutsche Forschungsgemeinschaft to RB (GRK 804 and SFB 832). This work was supported by the German Cancer Aid by a grant to the German HNPCC Consortium (speaker: PP).

\section{DISCLOSURE/CONFLICT OF INTEREST}

The authors declare no conflict of interest.

1. Genini $M$, Schwalbe $P$, Scholl FA, et al. Subtractive cloning and characterization of DRAL, a novel LIM-domain protein down-regulated in rhabdomyosarcoma. DNA Cell Biol 1997;16:433-442.

2. Bach I. The LIM domain: regulation by association. Mech Dev 2000;91:5-17.

3. Martin B, Schneider R, Janetzky S, et al. The LIM-only protein FHL2 interacts with beta-catenin and promotes differentiation of mouse myoblasts. J Cell Biol 2002;159:113-122.

4. Samson T, Smyth N, Janetzky S, et al. The LIM-only proteins FHL2 and FHL3 interact with alpha- and beta-subunits of the muscle alpha7beta1 integrin receptor. J Biol Chem 2004;279:28641-28652.

5. Wixler V, Geerts D, Laplantine E, et al. The LIM-only protein DRAL/FHL2 binds to the cytoplasmic domain of several alpha and beta integrin chains and is recruited to adhesion complexes. J Biol Chem 2000;275:33669-33678.

6. Morlon A, Sassone-Corsi P. The LIM-only protein FHL2 is a seruminducible transcriptional coactivator of AP-1. Proc Natl Acad Sci USA 2003;100:3977-3982.

7. Mueller MM, Fusenig NE. Friends or foes-bipolar effects of the tumour stroma in cancer. Nat Rev Cancer 2004;4:839-849.

8. Philippar U, Schratt G, Dieterich C, et al. The SRF target gene Fhl2 antagonizes RhoA/MAL-dependent activation of SRF. Mol Cell 2004; 16:867-880.

9. Wixler V, Hirner S, Muller JM, et al. Deficiency in the LIM-only protein Fhl2 impairs skin wound healing. J Cell Biol 2007;177:163-172.

10. Park J, Will C, Martin B, et al. Deficiency in the LIM-only protein FHL2 impairs assembly of extracellular matrix proteins. FASEB J 2008;22:2508-2520.

11. De Wever O, Mareel M. Role of tissue stroma in cancer cell invasion. J Pathol 2003;200:429-447.

12. Hinz B. Formation and function of the myofibroblast during tissue repair. J Invest Dermatol 2007;127:526-537.

13. Hinz B, Phan SH, Thannickal VJ, et al. The myofibroblast. One function, multiple origins. Am J Pathol 2007;170:1807-1816.

14. Ikushima $H$, Miyazono K. TGFbeta signalling: a complex web in cancer progression. Nat Rev Cancer 2010;10:415-424.
15. Brenmoehl J, Miller SN, Hofmann C, et al. Transforming growth factorbeta 1 induces intestinal myofibroblast differentiation and modulates their migration. World J Gastroenterol 2009;15:1431-1442.

16. Gabriel B, Fischer DC, Orlowska-Volk $M$, et al. Expression of the transcriptional coregulator $\mathrm{FHL2}$ in human breast cancer: a clinicopathologic study. J Soc Gynecol Investig 2006;13:69-75.

17. Gabriel B, Mildenberger S, Weisser CW, et al. Focal adhesion kinase interacts with the transcriptional coactivator FHL2 and both are overexpressed in epithelial ovarian cancer. Anticancer Res 2004; 24:921-927.

18. Kahl P, Gullotti L, Heukamp LC, et al. Androgen receptor coactivators lysine-specific histone demethylase 1 and four and a half LIM domain protein 2 predict risk of prostate cancer recurrence. Cancer Res 2006;66:11341-11347.

19. Zhang W, Jiang B, Guo Z, et al. Four-and-a-half LIM protein 2 promotes invasive potential and epithelial-mesenchymal transition in colon cancer. Carcinogenesis 2010;31:1220-1229.

20. Zhang W, Wang J, Zou B, et al. Four and a half LIM protein 2 (FHL2) negatively regulates the transcription of E-cadherin through interaction with Snail1. Eur J Cancer 2010;47:121-130.

21. Wang J, Yang $\mathrm{Y}, \mathrm{Xia} \mathrm{HH}$, et al. Suppression of FHL2 expression induces cell differentiation and inhibits gastric and colon carcinogenesis. Gastroenterology 2007;132:1066-1076.

22. Ruschoff J, Dietmaier W, Luttges J, et al. Poorly differentiated colonic adenocarcinoma, medullary type: clinical, phenotypic, and molecular characteristics. Am J Pathol 1997;150:1815-1825.

23. Friedrichs $\mathrm{N}$, Jager $\mathrm{R}$, Paggen $\mathrm{E}$, et al. Distinct spatial expression patterns of AP-2alpha and AP-2gamma in non-neoplastic human breast and breast cancer. Mod Pathol 2005;18:431-438.

24. Friedrichs $\mathrm{N}$, Steiner $\mathrm{S}$, Buettner $\mathrm{R}$, et al. Immunohistochemical expression patterns of AP2alpha and AP2gamma in the developing fetal human breast. Histopathology 2007;51:814-823.

25. Muller JM, Metzger E, Greschik $\mathrm{H}$, et al. The transcriptional coactivator FHL2 transmits Rho signals from the cell membrane into the nucleus. Embo j 2002;21:736-748.

26. Friedrichs $\mathrm{N}$, Kuchler $\mathrm{J}$, Endl $\mathrm{E}$, et al. Insulin-like growth factor-1 receptor acts as a growth regulator in synovial sarcoma. J Pathol 2008;216:428-439.

27. Fadok VA, de Cathelineau A, Daleke DL, et al. Loss of phospholipid asymmetry and surface exposure of phosphatidylserine is required for phagocytosis of apoptotic cells by macrophages and fibroblasts. J Biol Chem 2001:276:1071-1077.

28. Govoni KE, Amaar YG, Kramer A, et al. Regulation of insulin-like growth factor binding protein-5, four and a half lim-2, and a disintegrin and metalloprotease-9 expression in osteoblasts. Growth Horm IGF Res 2006;16:49-56.

29. Prud'homme GJ. Pathobiology of transforming growth factor beta in cancer, fibrosis and immunologic disease, and therapeutic considerations. Lab Invest 2007;87:1077-1091.

30. Tsushima $\mathrm{H}$, Kawata $\mathrm{S}$, Tamura $\mathrm{S}$, et al. High levels of transforming growth factor beta 1 in patients with colorectal cancer: association with disease progression. Gastroenterology 1996;110: 375-382.

31. Muller JM, Isele $U$, Metzger $E$, et al. $F H L 2$, a novel tissue-specific coactivator of the androgen receptor. EMBO J 2000;19:359-369.

32. Schwitalle $\mathrm{Y}$, Kloor $\mathrm{M}$, Eiermann $\mathrm{S}$, et al. Immune response against frameshift-induced neopeptides in HNPCC patients and healthy HNPCC mutation carriers. Gastroenterology 2008;134:988-997.

33. Schwitalle $\mathrm{Y}$, Linnebacher $\mathrm{M}$, Ripberger $\mathrm{E}$, et al. Immunogenic peptides generated by frameshift mutations in DNA mismatch repair-deficient cancer cells. Cancer Immun 2004:4:14

34. Zeisberg M, Strutz F, Muller GA. Role of fibroblast activation in inducing interstitial fibrosis. J Nephrol 2000;13(Suppl 3):S111-S120.

35. Gaggioli C, Hooper S, Hidalgo-Carcedo C, et al. Fibroblast-led collective invasion of carcinoma cells with differing roles for RhoGTPases in leading and following cells. Nat Cell Biol 2007;9:1392-1400.

36. Postlethwaite $A E$, Keski-Oja J, Moses $H L$, et al. Stimulation of the chemotactic migration of human fibroblasts by transforming growth factor beta. J Exp Med 1987;165:251-256. 